\title{
Yield gap of winter wheat in Europe and sensitivity of potential yield to climate factors
}

\author{
Shaoxiu Ma ${ }^{1,2,3,4,8, *}$, Galina Churkina ${ }^{5,6}$, Arthur Gessler $^{1,3,9}$, Ralf Wieland ${ }^{1}$, \\ Gianni Bellocchi ${ }^{7}$
}

${ }^{1}$ Leibniz Centre for Agricultural Landscape Research (ZALF), Eberswalder Straße 84, 15374 Müncheberg, Germany

${ }^{2}$ Max Planck Institute for Biogeochemistry, Hans-Knöll-Straße 10, 07745 Jena, Germany

${ }^{3}$ Faculty of Agriculture and Horticulture, Humboldt Universität zu Berlin, 12489 Berlin, Germany

${ }^{4}$ Key Laboratory of Desert and Desertification, Cold and Arid Regions Environmental and Engineering Research Institute, CAS, Lanzhou 730000, PR China

${ }^{5}$ Geography Department, Humboldt Universität zu Berlin, 12489 Berlin, Germany

${ }^{6}$ Institute for Advanced Sustainability Studies, Berliner Strasse 130, 14467 Potsdam, Germany

${ }^{7}$ INRA, UR0874 Grassland Ecosystem Research, 63039 Clermont-Ferrand, France

${ }^{8}$ Present address: Climate Change Research Centre, University of New South Wales (UNSW), Sydney, New South Wales 2052, Australia

${ }^{9}$ Present address: Swiss Federal Institute for Forest, Snow and Landscape Research (WSL), Zürcherstrasse 111, 8903 Birmensdorf, Switzerland

\begin{abstract}
It is not clear whether the changing climate in Europe will be favourable for crop yield in the future. In this study, we quantified the yield gap for the year 2000 and analyzed the sensitivity of the rain-fed potential yield of winter wheat to changes in temperature, precipitation, and $\mathrm{CO}_{2}$ across Europe. The ecosystem model ANTHRO-BGC was used to simulate potential yields; actual winter wheat yield data together with modelled potential yields were used to calculate yield gap. Artificial climate scenarios for the main climate factors used in sensitivity studies were generated according to climate scenarios from the IPCC 4th Assessment Report (AR4). We found that there is currently a large yield gap in Eastern Europe (around $6 \mathrm{t} \mathrm{ha}^{-1}$ ), whereas in a few developed countries in Western Europe the harvested yield approaches potential yield (around $2 \mathrm{t} \mathrm{ha}^{-1}$ ). Sensitivity analysis indicates that the rain-fed potential yield could increase by about $14 \%$ in Europe, under the assumption that the changes in temperature and precipitation will be the same as those projected for 2050 from AR4, and that $\mathrm{CO}_{2}$ will increase from 380 to $550 \mathrm{ppm}$. This increase in projected potential yield is mainly due to fertilization effects caused by increasing atmospheric $\mathrm{CO}_{2}$ concentrations (15\% yield increase), whereas the projected changes in temperature and precipitation will negatively $(-1 \%)$ affect the rain-fed potential yield in Europe.
\end{abstract}

KEY WORDS: Potential yield · Rain-fed potential yield - Yield gap · ANTHRO-BGC model · Winter wheat $\cdot$ Sensitivity analysis

Resale or republication not permitted without written consent of the publisher

\section{INTRODUCTION}

The issue of food production versus demand is of particular urgency in Europe because crop yields have been stagnating or even declining over the last
2 decades in many countries (Peltonen-Sainio et al. 2007, Brisson et al. 2010, Licker et al. 2013). Weather and climate influence agriculture directly, through a combination of changes in mean conditions and extreme events such as high temperature, drought, 
and heavy rain, and indirectly through sea-level rise and changes in the occurrence of pests and disease (Gornall et al. 2010, Lobell et al. 2013, Asseng et al. 2014). Current climate limitations on plant productivity will determine the future responses of plants to the warming climate (Churkina \& Running 1998). In warm climate zones, crop yield is likely to decrease (Asseng et al. 2014) since higher temperatures can shorten the period for grain filling and may cause stress for plants, especially at the time of flowering and seed-set. At higher latitudes, crop yields are likely to increase as warmer temperatures allow for longer growing seasons (Parry et al. 2004, Jaggard et al. 2010). A $2^{\circ} \mathrm{C}$ temperature increase at midlatitudes could increase wheat production by nearly $10 \%$, whereas at low latitudes the same temperature change may decrease yields by nearly the same amount (Gornall et al. 2010). The anthropogenic increase in atmospheric $\mathrm{CO}_{2}$ concentrations will also affect crop yields (McGrath \& Lobell 2011). Plants benefit from elevated $\mathrm{CO}_{2}$ concentrations through increases in photosynthesis and reductions in photorespiration (Ainsworth \& Long 2005). Moreover, high $\mathrm{CO}_{2}$ concentrations reduce stomatal conductance (Ainsworth \& Rogers 2007), which may decrease canopy transpiration and improve soil and plant water status, and thus crop yield (Leakey et al. 2006, Bernacchi et al. 2007). The increase from present $\mathrm{CO}_{2}$ concentrations to $550 \mathrm{ppm}$ could potentially increase $\mathrm{C}_{3}$ crop yields by $10-20 \%$, and $\mathrm{C}_{4}$ crop yields up to $10 \%$ (Long et al. 2004, Ainsworth \& Long 2005). Even though increased $\mathrm{CO}_{2}$ concentrations could increase water use efficiency, the concomitant temperature increase might counteract the beneficial effect of $\mathrm{CO}_{2}$ on water consumption by increasing the rate of evapotranspiration (Jaggard et al. 2010). The combined effects of high temperature, elevated $\mathrm{CO}_{2}$, and altered precipitation on crops are complex because of the interactions between different environmental drivers (Walker \& Schulze 2008); further studies are required to explore the sensitivity of potential crop yields to climate change.

Future climate changes may be beneficial for wheat in some regions, but could reduce productivity in areas where the temperature is currently optimal for growth (Asseng et al. 2014). Winter wheat yield in southern Sweden, for instance, is predicted to increase by $10-20 \%$ by 2050 (Eckersten et al. 2001), whereas wheat yield in southern Australia is likely to decrease between 13.5 and $32 \%$ under most climate change scenarios (Luo et al. 2005). The impact of future climate change on crop production has been studied using crop models and climate change sce- narios in some countries, e.g. Turkey (Ozdogan 2011), Belgium (Gobin 2010), and Italy (Dettori et al. 2011), and on a global scale (Balkovi et al. 2014, Rosenzweig et al. 2014). An assessment of the impacts of climate change on the potential yields of the main crops for rain-fed and irrigated agriculture in Europe, performed with the crop model WOFOST (van Diepen et al. 1989) and projected to the horizon in 2090, indicated positive effects of increasing $\mathrm{CO}_{2}$ concentration for wheat yield (Supit et al. 2012). Potential yield is the yield of an adapted crop variety or hybrid when grown under favourable conditions without any growth limitations from water, nutrients, pests, or diseases (Lobell et al. 2009, van Ittersum et al. 2013, van Wart et al. 2013a). Under rain-fed conditions, where the water supply for crop production is not under the control of the grower, the waterlimiting yield may be considered as the rain-fed potential yield for yield gap analysis, assuming other factors are not limiting crop growth (e.g. Wani et al. 2009). The objectives of the present study were (1) to quantify the potential yields of winter wheat Triticum aestivum L. in Europe from 1997-2003, and (2) to assess the sensitivity of potential yield to the predicted change in temperature, precipitation, and $\mathrm{CO}_{2}$ to the horizon in 2050. An important aspect of the methodology was an update and validation of the ecosystem model ANTHRO-BGC (Ma et al. 2011) for use in achieving both objectives.

\section{MATERIALS AND METHODS}

We used the global crop dataset from Monfreda et al. (2008) as a reference dataset for actual crop yields. Actual yields of winter wheat were compared with the potential yields estimated with the ANTHROBGC for Europe from 1997-2003. The Modified Climate Research Unit (MCRU) climate dataset (Mitchell \& Jones 2005, Chen et al. 2009) was used to drive the ANTHRO-BGC from 1948-2005.

\subsection{The ecosystem model ANTHRO-BGC}

The ANTHRO-BGC ecosystem model we used in this study was an updated version derived from the process-based model BIOME-BGC (Running \& Coughlan 1988, Thornton 1998), which was originally designed to represent natural ecosystems such as forests and grasslands. The model operates at a daily time step and describes the dynamics of energy, water, carbon, and nitrogen in natural and managed 
ecosystems. It includes a newly developed, cropspecific phenology approach, calibrated in Europe (Ma et al. 2012). In the new phenology approach, the start and length of the growing season are estimated based on climate variables depending on carbon fluxes (in turn depending on air temperature, vapour pressure deficit, and photoperiod). Gross primary production is calculated using the Farquhar photosynthesis routine (Farquhar et al. 1980, De Pury \& Farquhar 1997) separately for sunlit and shaded foliage. The routine includes the effect of $\mathrm{CO}_{2}$ fertilization on plants (De Pury \& Farquhar 1997). The eco-physiological parameters of ANTHRO-BGC for winter wheat were optimized using eddy covariance measurements of carbon and water fluxes in Europe for the period from 2005-2007 (Ma et al. 2011).

ANTHRO-BGC, which uses climate variables and atmospheric $\mathrm{CO}_{2}$ concentration as the driving variables of plant physiological processes, is known to effectively reproduce the key components of the carbon and water cycles (i.e. gross primary production, net ecosystem exchange of $\mathrm{CO}_{2}$, evapotranspiration) that are directly related to potential crop yield (Ma et al. 2011). The model was calibrated with observational eddy covariance, along with remotely sensed and phenological data from 7 cropland sites in Germany, Belgium, France, Switzerland, and Denmark (Ma et al. 2011, 2012). An assumption of this study was that the model, calibrated in Western European countries, can represent potential conditions in the rest of Europe. In the absence of detailed information on actual sowing dates (which depend on labour availability as well as economic and weather conditions; e.g. Sacks et al. 2010), sowing was set to occur 2 wk earlier than the onset of leaf greening (as estimated by the phenological model; Ma et al. 2012). We started with an analysis of the main climatic factors limiting the potential yield of winter wheat in Europe between 1997-2003 (see the Supplement at www.int-res.com/articles/suppl/c067p179_supp.pdf), followed by a quantification of the yield gap. The latter is defined as the difference between potential and actual yield, averaged over a given time period and spatial scale (Lobell et al. 2009, Boogaard et al. 2013). Finally, we performed a sensitivity analysis of the rain-fed potential yield to the assumed changes in temperature, precipitation, and atmospheric $\mathrm{CO}_{2}$ concentration.

Daily weather inputs (maximum and minimum temperatures, vapour pressure deficit, precipitation, and global solar radiation), gridded at $0.25^{\circ}$ resolution, were extracted from the MCRU dataset (Mitchell \& Jones 2005, Chen et al. 2009) and used to drive ANTHRO-BGC from 1948-2005. The MCRU dataset covers all climate variables necessary for the simulation at a daily time scale for all of Europe within the boundaries $15^{\circ} \mathrm{W}$ to $60^{\circ} \mathrm{E}$, and $30-75^{\circ} \mathrm{N}$ (which is not the case for other available datasets, e.g. the E-OBS dataset; http://eca.knmi.nl). The spin-up simulation was driven by climate data from the period 1960-1980, which were repeatedly used to bring soil carbon and nitrogen pools to nearequilibrium conditions.

The MCRU climate dataset was generated from the Climate Research Unit (CRU) dataset (which includes monthly climate variables), and the climate datasets from REMO or ECHAM5 (both providing variables with both monthly and daily resolutions). The procedure was based on the assumption of a linear relationship of monthly climate variables between CRU and REMO (Feser \& Weisse 2001) or ECHAM5 (www.mpimet.mpg.de/en/science/models/ echam.html) which can be used to estimate the daily climate variables for MCRU in 2 steps: (1) establishing the linear relationships between the monthly variables from CRU and REMO or ECHAM5 (Chen et al. 2009), and (2) generating the daily climate variables of MCRU according to these linear relationships and the daily climate data from REMO or ECHAM5.

Elevation and soil data (texture and depth) from a previous study (Vetter et al. 2008) were used in the model. Since we focused on the analysis of winter wheat, the $\mathrm{C}_{3}$ crop cultivated area in Europe was assumed to be covered by winter wheat.

\subsection{Potential wheat yields}

The potential yield of wheat was calculated as the aboveground biomass estimated at physiological maturity multiplied by the harvest index, the latter set to 0.4 (Gervois et al. 2008, Lobell et al. 2010). We acknowledge that the fixed value of harvest index (which does not account for heat/cold damages that occur during pollination and ripening) could introduce uncertainties to the estimated potential yields over large regions (e.g. Farooq et al. 2011, Wang et al. 2015). However, it is difficult to dynamically estimate the harvest index while also considering spatial and temporal variations (Soltani et al. 2005, Kemanian et al. 2007, Gervois et al. 2008). Nevertheless, we showed that the simulated potential yield of winter wheat for the Netherlands compares well with existing observations (see Section 3.1). 
To focus on the effects of climate on yield, we minimized the representation of human-related effects on yield increase. We removed virtually all nitrogen deficiency stresses to winter wheat by arbitrarily setting the nitrogen input rate at $2 \mathrm{~kg} \mathrm{~N} \mathrm{~m}^{2} \mathrm{~d}^{-1}$. Although wheat is a rain-fed crop in most countries, in order to explore whether water is a limiting factor for yield in Europe, yields from both potential and rain-fed conditions were estimated during the period 1948-2005, respectively removing and retaining the water limitations of croplands. Similarly to nitrogen, applying water at high rate $(+20 \mathrm{~mm}$ per rainy day) ensured that water limitations were removed without adding problems caused by water excess (whose effect was not considered by the model).

\subsection{Yield gap}

To quantify the yield gap in Europe, the simulated potential wheat yields were compared against the actual yields extracted from the global crop dataset provided by Monfreda et al. (2008), which is a reference dataset for actual crop yields. This global crop dataset provides croplands on a $5 \times 5 \min (\sim 10 \times$ $10 \mathrm{~km}$ ) latitude-longitude grid. For the purpose of simulations, we used $\sim 0.25^{\circ}$ grid points obtained by averaging 9 adjacent grid points. Specifically, we compared the average actual yield values for the period 1997-2003 against the estimated potential yield in 2000. We used the actual average yield data of Monfreda et al. (2008) because this dataset documents both average crop yields and crop cultivated areas for the period from 1997-2003 (which is not the case for the Eurostat dataset; http://ec.europa.eu/ eurostat/). The average yield for 1997-2003 provides a reference point for comparison with the estimated potential yield for Europe because wheat yields have been stagnating in Europe since the 1990s and reached a plateau during 1997-2003 in most of the countries, with limited inter-annual variability (Brisson et al. 2010).

The yield gap (Gap_Yp) was calculated as the difference between the average estimated potential yield (Yp) from 1997-2003 and the average actual yield ( $Y$ stat) during the same time period. The yield gap, in $\mathrm{t} \mathrm{ha}^{-1}$ and in percent of the actual yield (Gap_Yp_fraction), was calculated following Eqs. (1) and (2) respectively for each grid cell:

$$
\begin{gathered}
\text { Gap_Yp }=Y p-Y_{-} \text {stat } \\
\text { Gap_Yp_fraction }=\frac{Y p-Y_{-} \text {stat }}{Y_{-} \text {stat }} \times 100
\end{gathered}
$$

The same method was used to calculate the rainfed yield gap.

\subsection{Sensitivity testing}

A total of 5 scenarios were generated for the sensitivity analysis of simulated potential yield of wheat to climate change factors.

The averaged maximum, median, and minimum values of changes in temperature and precipitation from the ensemble simulation of 21 Global Circulation Models within the A1B emission scenario (Christensen et al. 2007) were added to the historical observed temperature and precipitation values from MCRU for the period 1997-2003 for alternative scenarios. The A1B emission scenario is one of the storylines developed by the Special Report on Emissions Scenarios used in the IPCC 4th Assessment Report (IPCC 2007), which assumes a balance between the use of fossil fuels and alternative energy sources. Its climate output therefore constitutes only one of many possible future realizations. The changes in temperature and precipitation (Table 1) for 2050 (the time horizon set for this analysis) were created based on half of the projected change for the period 20802099, as given by Christensen et al. (2007). In this way, without running a climate change scenario analysis (which would be beyond the scope of this paper), the variability obtained with the altered scenarios constructed here is well within expected future climate variations. Different combinations of the minimum, median, and maximum changes in temperature and precipitation produced the 5 climate change scenarios (S1-S5) (Table 2) used in this study (for sake of simplification, other scenarios obtained with the median statistics of temperature and precipitation changes were not considered in the analysis). Another simplification is that the potential yields within these scenarios were obtained by running ANTHRO-BGC with the generated temperature and precipitation data and the historical records of global solar radiation and vapour pressure deficit for the period 1997-2003.

For all 5 climate scenarios (S1-S5), we increased the atmospheric $\mathrm{CO}_{2}$ concentrations from 380 to $550 \mathrm{ppm}$ in 2050 as reported in previous studies (Long et al. 2004, Ainsworth \& Long 2005), so that the predicted effects of the increase in $\mathrm{CO}_{2}$ concentration on potential yield could be compared to the reported experiment results.

Two groups of model simulations were run (Tables 1 $\& 2$ ) in order to quantify the sensitivity of changing 
temperature, precipitation, and atmospheric $\mathrm{CO}_{2}$ concentrations on the rain-fed potential yield. The first group of model simulations (G1) took into account only the change in temperature and precipitation; the second group (G2) additionally considered the effect of the assumed $\mathrm{CO}_{2}$ concentration increase.

Table 1. Monthly temperature and precipitation changes (applied daily) for 2050 according to A1B emission scenario for 2080-2099 (IPCC 2007). Min., max., and median represent the minimum, maximum and median (50\%) temperature and precipitation changes among the predicted results of 21 climate models used to predict climate change (Christensen et al. 2007). The monthly changes applied daily imply that the amount of change for temperature and precipitation on each day within the month was the same, but changes in temperature and precipitation for each month are different

\begin{tabular}{|c|c|c|c|c|c|c|}
\hline & \multicolumn{3}{|c|}{ Temperature $\left({ }^{\circ} \mathrm{C}\right)$} & \multicolumn{3}{|c|}{ Precipitation (\%) } \\
\hline & \multicolumn{3}{|c|}{ Min. Median Max. } & \multicolumn{3}{|c|}{ Min. Median Max. } \\
\hline \multicolumn{7}{|c|}{ Northern Europe $\left(48-75^{\circ} \mathrm{N}\right)$} \\
\hline Jan & 1.3 & 2.15 & 4.1 & 4.5 & 7.5 & 12.5 \\
\hline Feb & 1.3 & 2.15 & 4.1 & 4.5 & 7.5 & 12.5 \\
\hline Mar & 1.05 & 1.55 & 2.65 & 0 & 6 & 10.5 \\
\hline Apr & 1.05 & 1.55 & 2.65 & 0 & 6 & 10.5 \\
\hline May & 1.05 & 1.55 & 2.65 & 0 & 6 & 10.5 \\
\hline Jun & 0.7 & 1.35 & 2.5 & -10.5 & 1 & 8 \\
\hline Jul & 0.7 & 1.35 & 2.5 & -10.5 & 1 & 8 \\
\hline Aug & 0.7 & 1.35 & 2.5 & -10.5 & 1 & 8 \\
\hline Sep & 0.95 & 1.45 & 2.7 & -2.5 & 4 & 6.5 \\
\hline Oct & 0.95 & 1.45 & 2.7 & -2.5 & 4 & 6.5 \\
\hline Nov & 0.95 & 1.45 & 2.7 & -2.5 & 4 & 6.5 \\
\hline Dec & 1.3 & 2.15 & 4.1 & 4.5 & 7.5 & 12.5 \\
\hline \multicolumn{7}{|c|}{ Southern Europe and Mediterranean $\left(30-48^{\circ} \mathrm{N}\right)$} \\
\hline Jan & 0.85 & 1.3 & 2.3 & -8 & -3 & 3 \\
\hline Feb & 0.85 & 1.3 & 2.3 & -8 & -3 & 3 \\
\hline Mar & 1 & 1.6 & 2.25 & -12 & -8 & -1 \\
\hline Apr & 1 & 1.6 & 2.25 & -12 & -8 & -1 \\
\hline May & 1 & 1.6 & 2.25 & -12 & -8 & -1 \\
\hline Jun & 1.35 & 2.05 & 3.25 & -26.5 & -12 & -1.5 \\
\hline Jul & 1.35 & 2.05 & 3.25 & -26.5 & -12 & -1.5 \\
\hline Aug & 1.35 & 2.05 & 3.25 & -26.5 & -12 & -1.5 \\
\hline Sep & 1.15 & 1.65 & 2.6 & -14.5 & -6 & -1 \\
\hline Oct & 1.15 & 1.65 & 2.6 & -14.5 & -6 & -1 \\
\hline Nov & 1.15 & 1.65 & 2.6 & -14.5 & -6 & -1 \\
\hline Dec & 0.85 & 1.3 & 2.3 & -8 & -3 & 3 \\
\hline
\end{tabular}

Table 2. Combinations of the minimum, median, and maximum changes in temperature and precipitation listed in Table 1 that were used to produce the 5 climate scenarios (S1-S5) in this study

\begin{tabular}{|ccc|}
\hline & Temperature & Precipitation \\
\hline S1 & Min. & Min. \\
S2 & Median & Median \\
S3 & Max. & Max. \\
S4 & Min. & Max. \\
S5 & Max. & Min. \\
\hline
\end{tabular}

Rain-fed potential yields from the G1 and G2 model simulations were used to separately investigate the effects of the projected temperature and precipitation changes with and without increased atmospheric $\mathrm{CO}_{2}$ concentrations. Average rain-fed potential yields simulated for 1997-2003 were used as a reference.

The yield change ( $Y_{-}$change) due to the changes in temperature and precipitation, in tons per hectare and in percent ( $Y$ _change_fraction), was calculated using Eqs. (3) and (4) for each grid cell:

$$
Y \_ \text {change }=Y p w_{-} S(i)-Y p w
$$

$Y \_$change_fraction $=\left[Y p w_{-} S(i)-Y p w\right] / Y p w \times 100$

where Ypw_S(i) represents the average rain-fed potential yield for any scenario $S(i)$ (with $i=1, \ldots, 5)$ for both groups (G1 and G2). Ypw represents the rainfed average potential yield during 1997-2003. $Y$ _change represents the change in the average rainfed potential yield between the $S(i)$ and reference simulation. Negative values indicate that yield decreased under the projected climate conditions.

\section{RESULTS AND DISCUSSION}

\subsection{Yield gap between 1997-2003}

Spatial patterns of yield gap were rendered out (using a smoothing option) in the form of pixelated European maps $\left(0.25^{\circ}\right.$ grid resolution) for the period between 1997-2003 (Fig. 1). On average, the estimated yield gap was $5.22 \mathrm{t} \mathrm{ha}^{-1}$ (Fig. 1a), while the rain-fed yield gap was smaller $\left(2.4 \mathrm{t} \mathrm{ha}^{-1}\right.$ : $68 \%$ of potential yield; Fig. 1b). The lower value for the rainfed yield gap points to the fact that water is an important limiting factor for crop production in some regions of Europe (EEA 2009). However, negative yield gaps occurring in some areas indicate that in these areas, the water supply is less limiting than that assumed in the simulations.

The average European yield gap of $5.22 \mathrm{t} \mathrm{ha}^{-1} \mathrm{cal}-$ culated here is higher than the yield gap of 2-4 $\mathrm{tha}^{-1}$ estimated by Boogaard et al. (2013) with the crop model WOFOST, which was calibrated against experimental data from wheat crops in the 1980s. This underestimation of the potential yield might be due to model calibration against lower wheat yields than in 1997-2003 (Fischer \& Edmeades 2010), or failing to consider adaption strategies of farmers (Balkovič et al. 2014, Moore \& Lobell 2014). Using Netherlands as an example, the potential yield of the current win- 

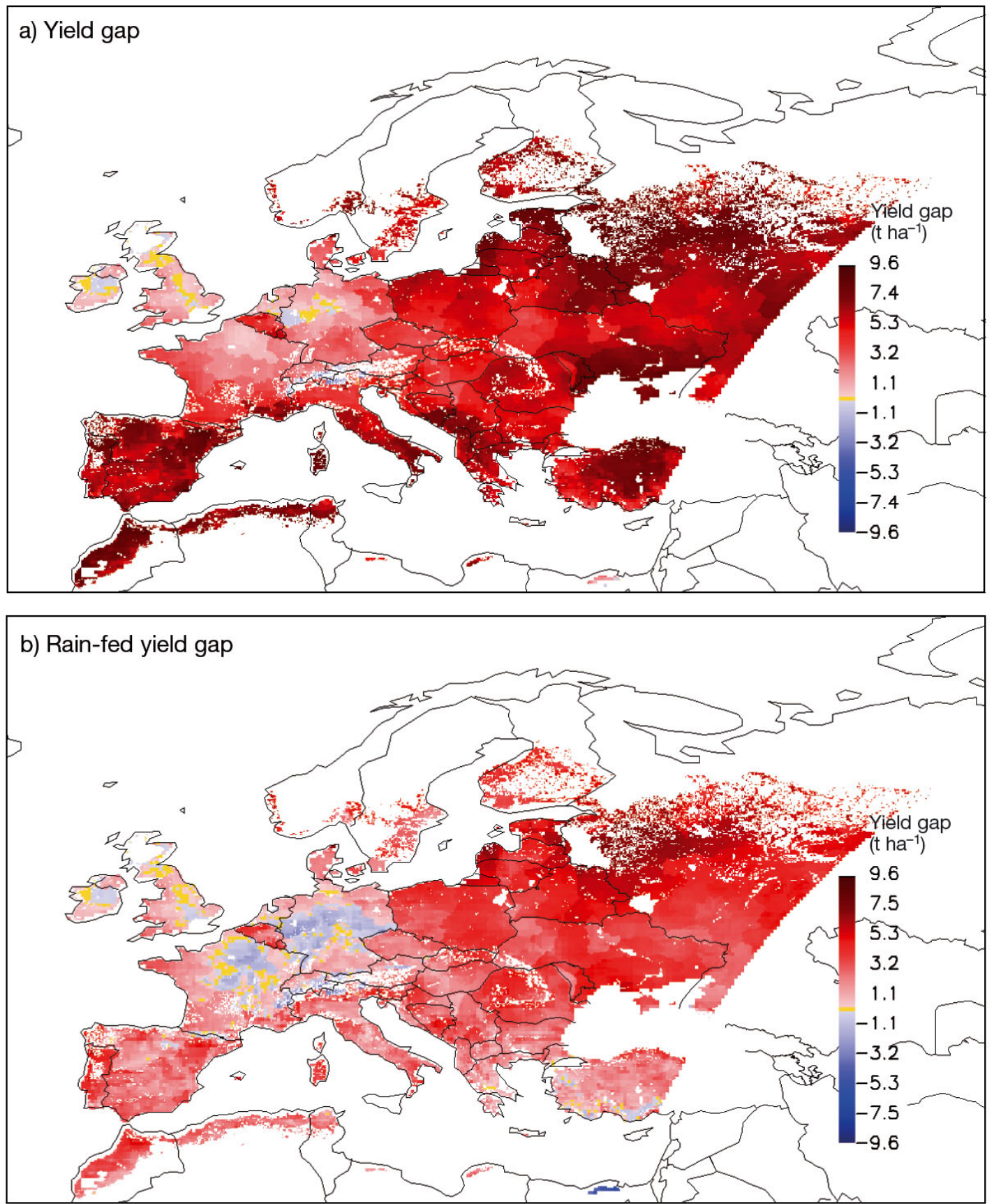

Fig. 1. Spatial distribution patterns of yield gaps in Europe between 1997-2003: (a) yield gap calculated as the difference between the averages of potential and actual yield, and (b) rain-fed yield gap calculated as the difference between the averages of the rain-fed potential and the actual yield

ter wheat variety determined from experiments is $9.6 \mathrm{t} \mathrm{ha}^{-1}$ (Boogaard et al. 2013). WOFOST underestimated this potential yield of winter wheat $\left(8.7 \mathrm{tha}^{-1}\right.$; Boogaard et al. 2013), while our estimation of $9.2 \mathrm{t}$ $\mathrm{ha}^{-1}$ is closer to the experimental value.

The estimated yield gap in Eastern Europe was larger than in Western Europe (Fig. 1) and the har- vested yield in several developed countries, such as Germany and France, was close to the potential yield (Fig. 1). Our results, along with those of a previous study (van Wart et al. 2013b), suggest that there is no substantial difference between Eastern and Western Europe in terms of potential yield production. The analysis of actual yields and management data 
indicates that wheat growth can be limited by nitrogen deficiency in Eastern Europe (Mueller et al. 2012). As a consequence, the yield gap difference between Eastern and Western Europe is mainly due to higher actual yields in Western Europe, where agricultural management is more advanced. This means that the yield production in Eastern Europe holds a potential for improvement in the future, with higher rates of fertilization and other advanced management techniques.

\subsection{Sensitivity of rain-fed potential yield to climate change}

The sensitivity to projected temperature and precipitation changes of the rain-fed potential yield were explored with and without the effects of the $\mathrm{CO}_{2}$ concentration increase. An assessment of the potential yield was not considered because wheat crops grown with water limitations respond more strongly to high $\mathrm{CO}_{2}$ concentrations than watersupplied crops (Gifford 1979).

\subsubsection{Sensitivity of rain-fed potential yield to changes in temperature and precipitation}

The simulation results showed that the rain-fed potential yields for Europe would increase by $0.02 \mathrm{t}$ $\mathrm{ha}^{-1}(+0.31 \%)$ and by $0.06 \mathrm{tha}^{-1}(+1 \%)$ in the S3 and S4 scenarios, respectively (Fig. 2). A decrease of $0.24 \mathrm{tha}^{-1}(-4.05 \%), 0.08 \mathrm{tha}^{-1}(-1.37 \%)$, and $0.27 \mathrm{t}$ $\mathrm{ha}^{-1}(-4.58 \%)$ was predicted for the S1, S2 and S5 scenarios, respectively (Fig. 2). This yield change is relative to the reference rain-fed potential yield of $5.93 \mathrm{t} \mathrm{ha}^{-1}$, which is the average for Europe during the period 1997-2003.

The strongest yield decrease (S5) and the greatest yield increase (S4) can be attributed to both the high sensitivity of the model to temperature and the positive effects of water supply on rain-fed potential yield. S5 assumes the largest increase in temperature and the lowest precipitation in 2050, whereas in contrast, S4 postulates the lowest temperature and highest precipitation in 2050. This result for Europe is in agreement with the finding that temperature increases cause grain yield reductions in cereals worldwide (Lobell \& Field 2007, Asseng et al. 2014, Bassu et al. 2014). With respect to the effects of both temperature and water on plant physiology, the differences between S5 and S4 are as would be expected.



Fig 2. Change in the rain-fed potential yield (\%) of Europe between climate scenarios S1-S5 and a reference simulation. Yield changes are calculated as differences between the estimated yields within climate scenarios and the reference (mean of 1997-2003). The differences were weighted with the cultivated area for each pixel as shown in Fig. 1. Black bars: response to changes in temperature and precipitation $(\mathrm{T}+\mathrm{P})$ only; dark grey bars: response to elevated $\mathrm{CO}_{2}$ concentration $\left(\mathrm{CO}_{2}\right)$ only; light grey bars: response to the 3 factors together $\left(\mathrm{T}+\mathrm{P}+\mathrm{CO}_{2}\right)$. Horizontal dashed line is for reference to compare bar height

The rain-fed yield changes in response to the changes in temperature and precipitation show a clear spatial pattern (Fig. 3). When the different scenarios are considered, the greatest increase in rainfed potential yield was seen in the relatively cool region of northern Europe, and the strongest decrease was estimated for southern Europe. This spatial pattern is consistent with the correlation between rain-fed potential yield and temperature as discussed in Section S2.3 in the Supplement at www.int-res. com/articles/suppl/c067p179_supp.pdf, and in previous studies (e.g. Asseng et al. 2014, Rosenzweig et al. 2014)

The spatial patterns of rain-fed potential yield in response to climate change, as shown in this study, are corroborated by several studies at the regional and site level. For autumn-sown crops (such as winter wheat), the impact of climate change on yield has been shown to be geographically variable (Olesen et al. 2007, Balkovi et al. 2014). These authors expected yields to strongly decrease across large parts of southern Europe (e.g. north of Portugal and Spain), but to increase in the cooler, northern areas, where presently rather low temperatures and levels of radiation are crop-growth limiting factors. Other studies also support the expectation of increased future crop yields in the northern parts of Europe, while large yield reductions are projected for the Mediterranean and the south-western Balkan regions as well as southern parts of European Russia (Olesen \& Bindi 2002, Maracchi et al. 2005, Alcamo et al. 2007). 

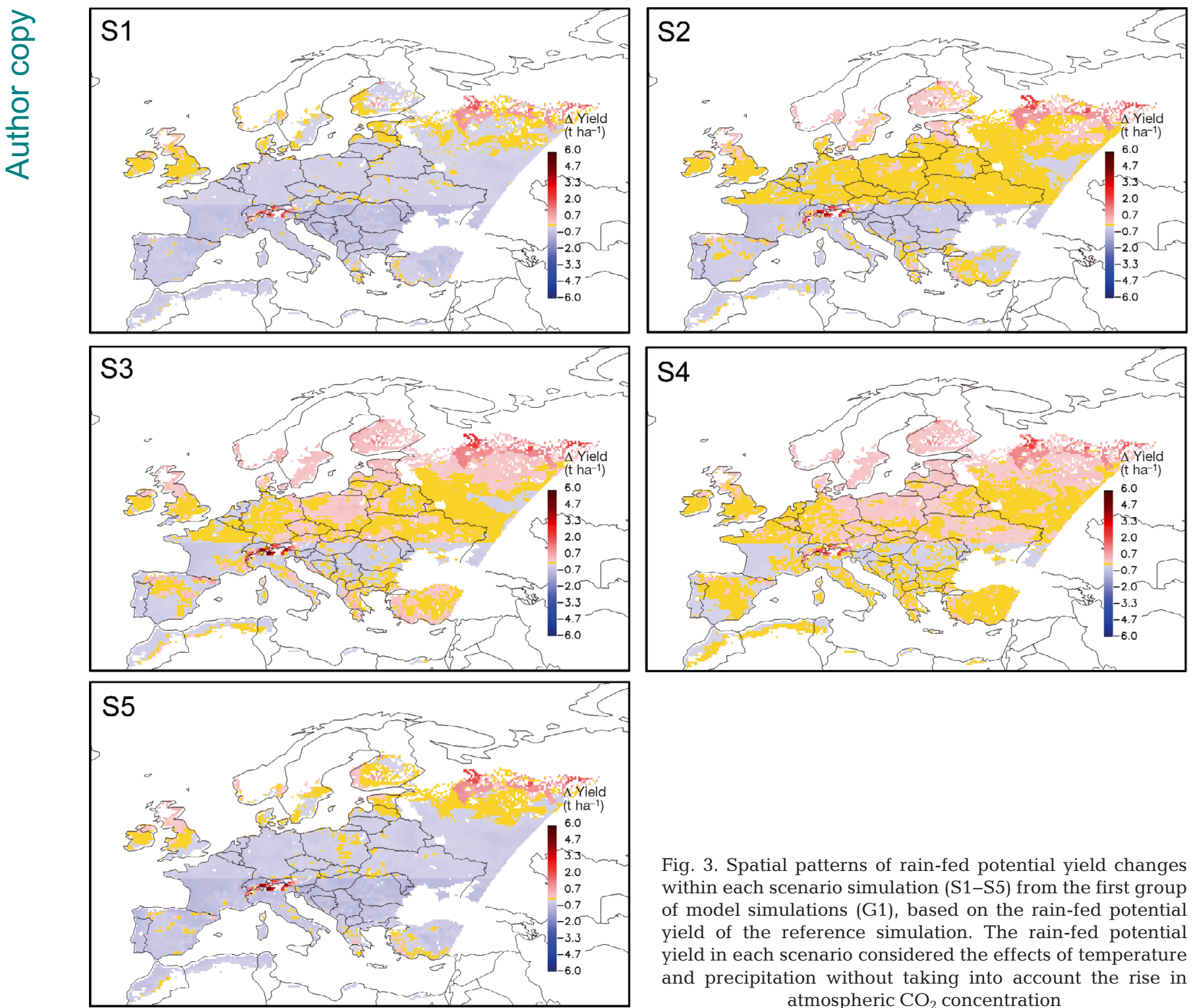

Fig. 3. Spatial patterns of rain-fed potential yield changes within each scenario simulation (S1-S5) from the first group of model simulations (G1), based on the rain-fed potential yield of the reference simulation. The rain-fed potential yield in each scenario considered the effects of temperature and precipitation without taking into account the rise in atmospheric $\mathrm{CO}_{2}$ concentration

3.2.2. Sensitivity of rain-fed potential yield to temperature, precipitation, and atmospheric $\mathrm{CO}_{2}$ concentration

Taking the impact of increased atmospheric $\mathrm{CO}_{2}$ concentrations into account, we estimated the rainfed potential yield to increase by $11-17 \%$ (depending on the scenario) for Europe (Figs. $2 \& 4$ ). Considering that the likelihood of any given scenario is subject to a degree of uncertainty (which makes it difficult to develop the most likely one), we treated all scenarios (S1-S5) as being equally likely to occur. Even though the likelihood of Scenario S2 (median temperature and median precipitation) would be higher than the other min./max. combinations, we represented the central tendency of all the scenarios (as in similar studies, e.g. Eitzinger et al. 2013). In this way, as an average for Europe and for the 5 scenarios, rain-fed potential yield increased by about $15 \%$ solely due to the increase in atmospheric $\mathrm{CO}_{2}$ concentration to $550 \mathrm{ppm}$. The effects of increasing $\mathrm{CO}_{2}$ concentrations on crop yields predicted here are in agreement with previous studies, which estimated that a comparable rise in atmospheric $\mathrm{CO}_{2}$ concentrations could increase $\mathrm{C}_{3}$ crop yields by $10-20 \%$ on average (Long et al. 2004, Ainsworth \& Long 2005). The increase in rain-fed potential yield of winter wheat $(14 \%)$ within the scenarios assessed in this study is slightly lower than the comparable estimates of $19 \%$ by Supit et al. (2012) (set to an average 

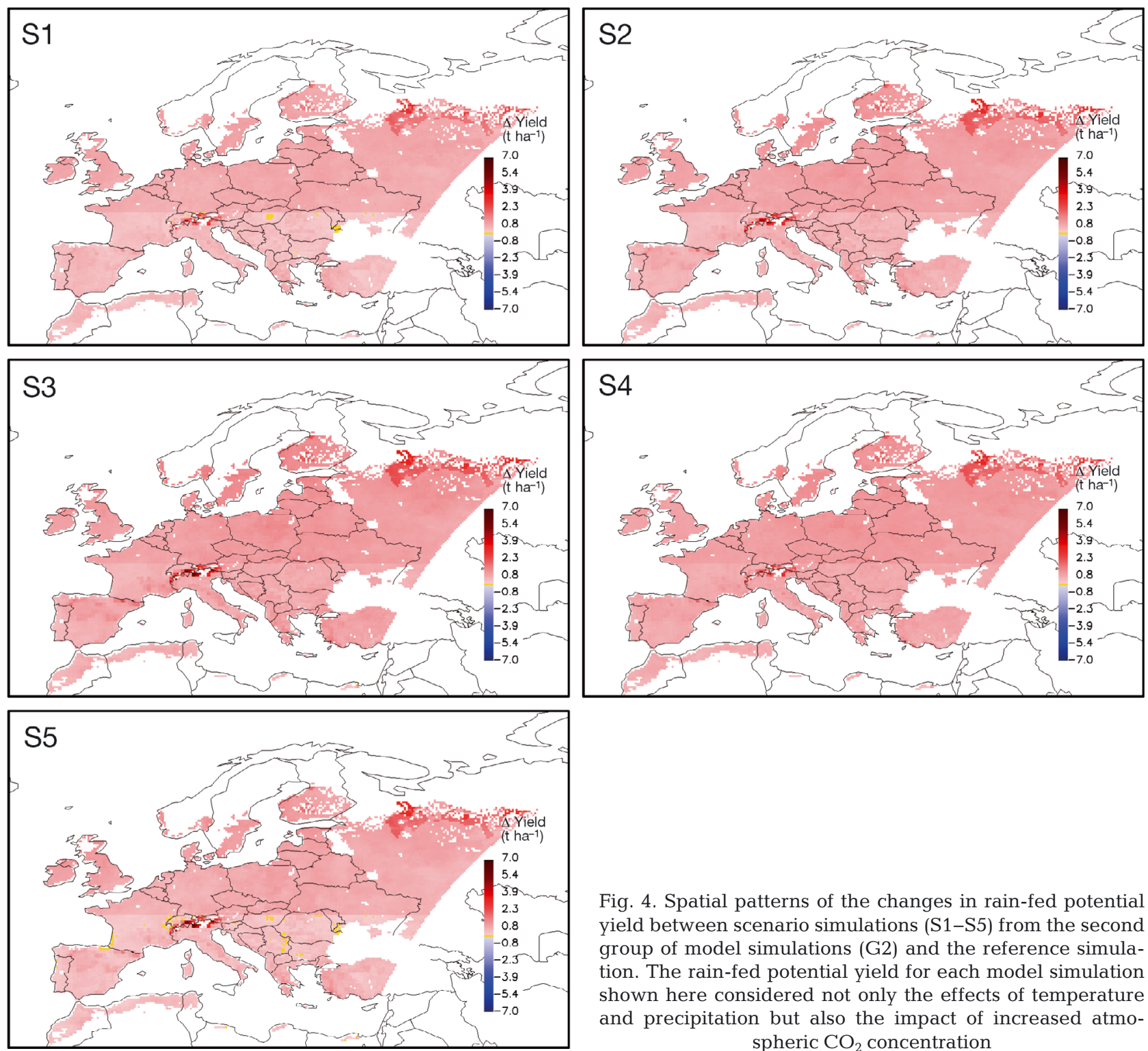

Fig. 4. Spatial patterns of the changes in rain-fed potential yield between scenario simulations (S1-S5) from the second group of model simulations (G2) and the reference simulation. The rain-fed potential yield for each model simulation shown here considered not only the effects of temperature and precipitation but also the impact of increased atmospheric $\mathrm{CO}_{2}$ concentration

value). The differences arise from the following points. (1) ANTHRO-BGC includes a dynamic phenology model for crops (Ma et al. 2012) instead of assuming fixed sowing dates as in WOFOST (Supit et al. 2012). Therefore, the growing season of winter wheat simulated by ANTHRO-BGC follows changes in weather conditions over a period of years. The length of the growing season has significant impacts on plant production (Churkina et al. 2005, Ma et al. 2012). In fact, an earlier growing season with the less favourable solar radiation conditions in early spring may limit crop productivity. (2) Although Supit et al. (2012) used data from different climate models as inputs for WOFOST, their model did not take into account the ability of plants to adapt to the changes in climatic conditions by modifying their morphology and physiology. This introduces uncertainty in yield estimation since, according to the projection of climate models, the frequency of adverse weather events are expected to increase (Trnka et al. 2014), but the plants' adaptability to such changing conditions were not taken into account.

The rain-fed potential yield within the projected scenarios is predicted to increase by about $14 \%$ when the effects of the projected temperature and precipitation change as well as the elevated $\mathrm{CO}_{2}$ concentration are taken into account. This is the result of a $15 \%$ increase due to increasing $\mathrm{CO}_{2}$ concentration and a $1 \%$ decrease due to future projected temperature and precipitation changes. 


\section{CONCLUSIONS}

The spatial distribution of the yield gap is helpful to show where and how yield production can be improved, while the estimation of the future potential yield gives an idea about the future food supply (Balkovi et al. 2014). In this study, a larger yield gap was estimated for Eastern than for Western Europe. Our simulated potential yield (ca. $9.2 \mathrm{t} \mathrm{ha}^{-1}$ ) and rainfed potential yield (ca. $8.5 \mathrm{t} \mathrm{ha}^{-1}$ ) was closer to the actual yield of winter wheat (ca. $7 \mathrm{t} \mathrm{ha}^{-1}$ ) in several developed countries, such as Germany and France during 1997-2003. The rain-fed potential yield of winter wheat could increase by $11-17 \%$ in Europe within the projected climate scenarios as a result of changes in temperature, precipitation, and $\mathrm{CO}_{2}$ concentration. We estimated that the $\mathrm{CO}_{2}$ concentration increase from 380 to $550 \mathrm{ppm}$ could alone cause an average increase of $15 \%$ in rain-fed potential yield. In contrast, the average changes in temperature and precipitation may have slightly negative effects $(-1 \%)$ on the rain-fed potential yield in Europe. Precipitation and radiation were the most limiting climatic factors for winter wheat growth in Europe (as discussed in the Supplement, www.int-res.com/ articles/suppl/m067p179_supp.pdf). An earlier start to the growing season due to warmer spring temperatures, combined with still relatively low solar radiation at that time likely resulted in lower yields for some parts of Europe. We acknowledge that the uncertainties in modelled yields may be substantial, as they originate from the model structure and parameterization as well as from forcing agents (Jung et al. 2007). A measure of the central tendency of a population of yield values estimated with multiple crop models can result in a better agreement with observed yields compared to any single model prediction (e.g. Asseng et al. 2013, Challinor et al. 2014, Rosenzweig et al. 2014). Moreover, the objective of this study was to run a sensitivity analysis on 2 climate variables (that is, a simulation exercise to assess the sensitivity of the crop model to changes in temperature and precipitation), not a climate change impact study. Therefore, it is mainly useful for ANTHRO-BGC users, but can be of interest for members of the modelling community who are performing simulation experiments over Europe, in that the results illustrated here for ANTHRO-BGC can be compared with the sensitivity of other models. An interesting perspective would be to superimpose the climate changes projected by climate models with the emission scenarios used by the 5th IPCC Assessment Report (IPCC 2013), to the curr ent sensitivity analysis and extend the analysis to global gridded crop modelling to construct envelopes of simulated yield.

Acknowledgements. The PhD scholarship was provided to S.M. by the Max Planck Society (MPG), Germany and the Chinese Academy of Sciences (CAS) through a joint doctoral program and by the Leibniz-Centre for Agricultural Landscape Research (ZALF). A.G. acknowledges financial support by the German Research council (DFG). G.B. received funding from the European Community's Seventh Framework Programme (FP7/2007-2013) under grant agreements no. 613817 (MODEXTREME, http://modextreme. org).

\section{LITERATURE CITED}

Ainsworth EA, Long SP (2005) What have we learned from 15 years of free-air $\mathrm{CO}_{2}$ enrichment (FACE)? A metaanalytic review of the responses of photosynthesis, canopy properties and plant production to rising $\mathrm{CO}_{2}$. New Phytol 165:351-371

Ainsworth EA, Rogers A (2007) The response of photosynthesis and stomatal conductance to rising $\left[\mathrm{CO}_{2}\right]$ : mechanisms and environmental interactions. Plant Cell Environ 30:258-270

Alcamo J, Moreno JM, Nováky B, Bindi M and others (2007) Europe. In: Parry ML, Canziani OF, Palutikof JP, van der Linden PJ, Hanson CE (eds) Climate change 2007: impacts, adaptation and vulnerability. Contribution of Working Group II to the Fourth Assessment Report of the Intergovernmental Panel on Climate Change. Cambridge University Press, Cambridge, p 541-580

Asseng S, Ewert F, Rosenzweig C, Jones JW and others (2013) Uncertainty in simulating wheat yields under climate change. Nat Clim Change 3:827-832

Asseng S, Ewert F, Martre P, Rötter RP and others (2014) Rising temperatures reduce global wheat production. Nat Clim Change 5:143-147

Balkovi J, van der Velde M, Skalský R, Xiong W and others (2014) Global wheat production potentials and management flexibility under the representative concentration pathways. Glob Planet Change 122:107-121

Bassu S, Brisson N, Durand JL, Boote K and others (2014) How do various maize crop models vary in their responses to climate change factors? Glob Change Biol 20:2301-2320

Bernacchi CJ, Kimball BA, Quarles DR, Long SP, Ort DR (2007) Decreases in stomatal conductance of soybean under open-air elevation of $\left[\mathrm{CO}_{2}\right]$ are closely coupled with decreases in ecosystem evapotranspiration. Plant Physiol 143:134-144

Boogaard H, Wolf J, Supit I, Niemeyer S, van Ittersum M (2013) A regional implementation of WOFOST for calculating yield gaps of autumn-sown wheat across the European Union. Field Crops Res 143:130-142

Brisson N, Gate P, Gouache D, Charmet G, Oury FX, Huard F (2010) Why are wheat yields stagnating in Europe? A comprehensive data analysis for France. Field Crops Res 119:201-212

Challinor AJ, Watson J, Lobell DB, Howden SM, Smith DR, Chhetri N (2014) A meta-analysis of crop yield under 
climate change and adaptation. Nat Clim Change 4: 287-291

Chen Y, Galina C, Martin H (2009) Constructing a consistent historical climate data set for the European domain. Tech Rep No. 15, Max Planck Institute for Biogeochemistry, Jena

Christensen JH, Hewitson B, Busuioc A, Chen A and others (2007) Regional climate projections. In: Solomon S, Qin $\mathrm{D}$, Manning $\mathrm{M}$, Chen $\mathrm{Z}$ and others (eds) Climate change 2007: the physical science basis. Contribution of Working Group I to the Fourth Assessment Report of the Intergovernmental Panel on Climate Change. Cambridge University Press, Cambridge, p 849-940

Churkina G, Running SW (1998) Contrasting climatic controls on the estimated productivity of global terrestrial biomes. Ecosystems 1:206-215

Churkina G, Schimel D, Braswell BH, Xiao X (2005) Spatial analysis of growing season length control over net ecosystem exchange. Glob Change Biol 11:1777-1787

De Pury DGG, Farquhar GD (1997) Simple scaling of photosynthesis from leaves to canopies without the errors of big-leaf models. Plant Cell Environ 20:537-557

Dettori M, Cesaraccio C, Motroni A, Spano D, Duce P (2011) Using CERES-Wheat to simulate durum wheat production and phenology in southern Sardinia, Italy. Field Crops Res 120:179-188

Eckersten H, Blombaeck K, Kaetterer T, Nyman P (2001) Modelling $\mathrm{C}, \mathrm{N}$, water and heat dynamics in winter wheat under climate change in southern Sweden. Agric Ecosyst Environ 86:221-235

EEA (European Environment Agency) (2009) Water resources across Europe-confronting water scarcity and drought. EEA Report No. 2/2009, European Environment Agency, Copenhagen

Eitzinger J, Štastná M, Žalud Z, Dubrovský M (2013) A simulation study of the effect of soil water balance and water stress on winter wheat production under different climate change scenarios. Agric For Meteorol 61:195-217

Farooq M, Bramley H, Palto JA, Siddique KHM (2011) Heat stress in wheat during reproductive and grain-filling phases. Crit Rev Plant Sci 30:491-507

Farquhar GD, Caemmerer S, Berry JA (1980) A biochemical model of photosynthetic $\mathrm{CO}_{2}$ assimilation in leaves of species. Planta 149:78-90

Feser F, Weisse R (2001) Multi-decadal atmospheric modeling for Europe yields multi-purpose data. EOS Trans Am Geophys Union 82:305-310

Fischer RA, Edmeades GO (2010) Breeding and cereal yield progress. Crop Sci 50(Suppl):S-85-S-98

Gervois S, Ciais P, de Noblet-Ducoudr N, Brisson N, Vuichard N, Viovy N (2008) Carbon and water balance of European croplands throughout the 20th century. Glob Biogeochem Cycles 22:GB2022, doi:10.1029/2007GB 003018

Gifford RM (1979) Growth and yield of $\mathrm{CO}_{2}$-enriched wheat under water-limited conditions. Aust J Plant Physiol 6: 367-378

Gobin A (2010) Modelling climate impacts on crop yields in Belgium. Clim Res 44:55-68

Gornall J, Betts R, Burke E, Clark R, Camp J, Willett K, Wiltshire A (2010) Implications of climate change for agricultural productivity in the early twenty-first century. Philos Trans R Soc Lond B Biol Sci 365:2973-2989

IPCC (2007) Climate change 2007: the physical science basis. Contribution of Working Group I to the Fourth
Assessment Report of the Intergovernmental Panel on Climate Change. Cambridge University Press, Cambridge

IPCC (2013) Climate change 2013: the physical science basis. Contribution of Working Group I to the Fifth Assessment Report of the Intergovernmental Panel on Climate Change. Cambridge University Press, Cambridge

Jaggard KW, Qi A, Ober ES (2010) Possible changes to arable crop yields by 2050. Philos Trans R Soc Lond B Biol Sci 365:2835-2851

Jung M, Vetter M, Herold M, Churkina G and others (2007) Uncertainties of modeling gross primary productivity over Europe: a systematic study on the effects of using different drivers and terrestrial biosphere models. Glob Biogeochem Cycles 21:GB4021, doi:10.1029/2006GB 002915

Kemanian AR, Stöckle CO, Huggins DR, Viega LM (2007) A simple method to estimate harvest index in grain crops. Field Crops Res 103:208-216

Leakey AD, Bernacchi CJ, Ort DR, Long SP (2006) Longterm growth of soybean at elevated $\left[\mathrm{CO}_{2}\right]$ does not cause acclimation of stomatal conductance under fully open-air conditions. Plant Cell Environ 29:1794-1800

Licker R, Kucharik CJ, Doré T, Lindeman MJ, Makowski D (2013) Climatic impacts on winter wheat yields in Picardy, France and Rostov, Russia: 1973-2010. Agric For Meteorol 176:25-37

Lobell DB, Field CB (2007) Global scale climate-crop yield relationships and the impacts of recent warming. Environ Res Lett 2:014002, doi:10.1088/1748-9326/2/1/ 014002

Lobell DB, Cassman KG, Field CB (2009) Crop yield gaps: their importance, magnitudes, and causes. Annu Rev Environ Resour 34:179-204

Lobell DB, Ortiz-Monasterio JI, Lee AS (2010) Satellite evidence for yield growth opportunities in Northwest India. Field Crops Res 118:13-20

Lobell DB, Hammer GL, McLean G, Messina C, Roberts MJ, Schlenker W (2013) The critical role of extreme heat for maize production in the United States. Nat Clim Change 3:497-501

Long SP, Ainsworth EA, Rogers A, Ort DR (2004) Rising atmospheric carbon dioxide: plants FACE the future. Annu Rev Plant Biol 55:591-628

Luo Q, Bellotti W, Williams M, Bryan B (2005) Potential impact of climate change on wheat yield in South Australia. Agric For Meteorol 132:273-285

Ma S, Churkina G, Wieland R, Gessler A (2011) Optimization and evaluation of the ANTHRO-BGC model for winter crops in Europe. Ecol Modell 222:3662-3679

Ma S, Churkina G, Trusilova K (2012) Investigating the impact of climate change on crop phenological events in Europe with a phenology model. Int J Biometeorol 56: 749-763

Maracchi G, Sirotenko O, Bindi M (2005) Impacts of present and future climate variability on agriculture and forestry in the temperate regions: Europe. In: Salinger J, Sivakumar MVK, Motha RP (eds) Increasing climate variability and change. Springer Netherlands, Amsterdam, p 117-135

McGrath JM, Lobell DB (2011) An independent method of deriving the carbon dioxide fertilization effect in dry conditions using historical yield data from wet and dry years. Glob Change Biol 17:2689-2696 
Mitchell TD, Jones PD (2005) An improved method of constructing a database of monthly climate observations and associated high-resolution grids. Int $\mathrm{J}$ Climatol 25: 693-712

Monfreda C, Ramankutty N, Foley JA (2008) Farming the planet. 2. Geographic distribution of crop areas, yields, physiological types, and net primary production in the year 2000. Glob Biogeochem Cycles 22:GB1022, doi: 10.1029/2007GB002947

> Moore FC, Lobell DB (2014) Adaptation potential of European agriculture in response to climate change. Nat Clim Change 4:610-614

Mueller ND, Gerber JS, Johnston M, Ray DK, Ramankutty N, Foley JA (2012) Closing yield gaps through nutrient and water management. Nature 490:254-257

Olesen JE, Bindi M (2002) Consequences of climate change for European agricultural productivity, land use and policy. Eur J Agron 16:239-262

Olesen J, Carter T, Diaz-Ambrona C, Fronzek S and others (2007) Uncertainties in projected impacts of climate change on European agriculture and terrestrial ecosystems based on scenarios from regional climate models. Clim Change 81:123-143

Ozdogan M (2011) Modeling the impacts of climate change on wheat yields in northwestern Turkey. Agric Ecosyst Environ 141:1-12

Parry ML, Rosenzweig C, Iglesias A, Livermore M, Fischer G (2004) Effects of climate change on global food production under SRES emissions and socio-economic scenarios. Glob Environ Change 14:53-67

Peltonen-Sainio P, Jauhiainen L, Hannukkala A (2007) Declining rapeseed yields in Finland: How, why and what next? J Agric Sci 145:587-598

Rosenzweig C, Elliott J, Deryng D, Ruane AC and others (2014) Assessing agricultural risks of climate change in the 21st century in a global gridded crop model intercomparison. Proc Natl Acad Sci USA 111:3268-3273

Running SW, Coughlan JC (1988) A general model of forest ecosystem processes for regional applications. I. Hydrologic balance, canopy gas exchange and primary production processes. Ecol Modell 42:125-154

Sacks WJ, Deryng D, Foley JA, Ramankutty N (2010) Crop planting dates: an analysis of global patterns. Glob Ecol Biogeogr 19:607-620

Soltani A, Torabi B, Zarei H (2005) Modeling crop yield

Editorial responsibility: Toshichika Iizumi,

Tsukuba, Japan using a modified harvest index-based approach: application in chickpea. Field Crops Res 91:273-285

Supit I, van Diepen CA, de Wit AJW, Wolf J, Kabat P, Baruth B, Ludwig F (2012) Assessing climate change effects on European crop yields using the Crop Growth Monitoring System and a weather generator. Agric For Meteorol 164:96-111

Thornton PE (1998) Regional ecosystem simulation: combining surface- and satellite-based observations to study linkages between terrestrial energy and mass budgets. $\mathrm{PhD}$ dissertation, University of Montana, Missoula, MT

> Trnka M, Rötter RP, Ruiz-Ramos M, Kersebaum KC, Olesen JE, Žalud Z, Semenov MA (2014) Adverse weather conditions for European wheat production will become more frequent with climate change. Nat Clim Change 4: 637-643

van Diepen CA, Wolf J, van Keulen H, Rappoldt C (1989) WOFOST: a simulation model of crop production. Soil Use Manag 5:16-24

> van Ittersum MK, Cassman KG, Grassini P, Wolf J, Tittonell P, Hochman Z (2013) Yield gap analysis with local to global relevance - a review. Field Crops Res 143:4-17

> van Wart J, Kersebaum KC, Peng S, Milner M, Cassman KG (2013a) Estimating crop yield potential at regional to national scales. Field Crops Res 143:34-43

van Wart J, van Bussel LGJ, Wolf J, Licker R and others (2013b) Use of agro-climatic zones to upscale simulated crop yield potential. Field Crops Res 143:44-55

Vetter M, Churkina G, Jung M, Reichstein M and others (2008) Analyzing the causes and spatial pattern of the 2003 carbon flux anomaly in Europe using seven models. Biogeosciences 5:561-583

- Walker NJ, Schulze RE (2008) Climate change impacts on agro-ecosystem sustainability across three climate regions in the maize belt of South Africa. Agric Ecosyst Environ 124:114-124

> Wang X, Dinler BS, Vignjevic M, Jacobsen S, Wollenweber B (2015) Physiological and proteome studies of responses to heat stress during grain filling in contrasting wheat cultivars. Plant Sci 230:33-50

Wani SP, Rockstrom J, Oweis T (2009) Rainfed agriculture: unlocking the potential. In: Wani SP, Rockström J, Oweis $\mathrm{T}$ (eds) Comprehensive assessment of water management in agriculture series, Vol 7. CAB International, Wallingford

Submitted: March 30, 2015; Accepted: December 14, 2015 Proofs received from author(s): February 22, 2016 